\title{
Effects of factors released from eggs and other agents on cyclic nucleotide concentrations of sea urchin spermatozoa
}

\author{
D. L. Garbers and G. S. Kopf \\ Departments of Pharmacology and Physiology, Vanderbilt University School of Medicine, \\ Nashville, Tennessee 37232, U.S.A.
}

\begin{abstract}
Summary. Factors released from eggs (FRE) of the sea urchin, Strongylocentrotus purpuratus, caused up to 20-fold increases in sperm cyclic AMP levels after a 1-min incubation. Putative cyclic nucleotide phosphodiesterase inhibitors such as theophylline acted in a synergistic manner with FRE to cause even greater increases in sperm cyclic AMP levels. This effect appeared to be specific for egg factors since various hormones (triiodothyronine, norepinephrine, histamine), nucleosides (adenosine, guanosine), nucleophiles (azide), anaesthetics (procaine), ionophores (X537A, A23187), metals $\left(\mathrm{Mn}^{2+}\right)$ and neurotransmitters (acetylcholine) did not increase sperm cyclic AMP levels. Various mammalian tissue extracts (serum, uterus, adrenal, ovary, lung) also had no effect.

We suggest that the activity which elevates the cyclic AMP of sea urchin spermatozoa is specifically associated with sea urchin eggs.
\end{abstract}

\section{Introduction}

Sperm motility, respiration rate and fructolytic rate can be maintained or increased by cyclic nucleotide phosphodiesterase inhibitors and by exogenous adenosine $3^{\prime}: 5^{\prime}$-monophosphate (cyclic AMP) or guanosine 3':5'-monophosphate (cyclic GMP) (Garbers, Lust, First \& Lardy, 1971a; Garbers, First, Sullivan \& Lardy, 1971b; Garbers, First \& Lardy, 1973a; Garbers, First, Gorman \& Lardy, 1973b; Hoskins, 1973; Frenkel, Peterson \& Freund, 1973; Morton, Harrigan-Lum, Albagli \& Jooss, 1974; Schoenfeld, Amelar \& Dubin, 1975). These reports, and observations of high activities of cyclic AMP-dependent protein kinase (Hoskins, Casillas \& Stephens, 1972; Garbers, First \& Lardy, 1973c; Lee \& Iverson, 1976), guanylate cyclase (Garbers, Hardman \& Rudolph, 1974; Gray, Drummond, Luk, Hardman \& Sutherland, 1976), cyclic nucleotide phosphodiesterase (Gray et al., 1976; Tash, 1976; Wells \& Garbers, 1976), phosphoprotein phosphatase (Tang \& Hoskins, 1975) and adenylate cyclase (Casillas \& Hoskins, 1971 ; Braun \& Dods, 1975; Herman, Zahler, Doak \& Campbell, 1976; Garbers, 1977) in the spermatozoa of various animal species, have led to speculation that the cyclic nucleotides may be involved in the modulation of various sperm functions (Garbers et al., 1971a; Morton \& Albagli, 1973; Rogers \& Morton, 1973; Hoskins \& Casillas, 1974; Toyoda \& Chang, 1974; Rosado, Hicks, Reyes \& Blanco, 1974). Potent natural effectors of sperm cyclic nucleotide metabolism, however, were discovered only recently (Garbers \& Hardman, 1975, 1976). Factors released from sea urchin eggs (FRE) were shown to elevate sperm cyclic AMP levels by as much as 100 -fold within $0.5 \mathrm{~min}$. It has since been reported that the same factor which elevates sperm cyclic AMP levels also stimulates sperm respiratory rates (Kopf \& Garbers, 1977). Although these observations lend strong support to the previous speculations, the specificity of the FRE-induced cyclic AMP elevation in sea urchin spermatozoa has not been studied.

We therefore investigated a number of substances known to increase cyclic nucleotide levels in other cells, and extracts from a number of mammalian tissues, for their effects on sperm cyclic AMP and cyclic GMP concentrations.

\section{Materials and Methods}

Sea urchins (Strongylocentrotus purpuratus) were obtained from Pacific Bio-Marine, Venice, California. Unlabelled nucleotides and other drugs were from Sigma, Schwartz/Mann, Fisher, Hoffmann-La Roche or Eli Lilly. Dowex-50 (AG 50W X8, 100-200 mesh) was from Big-Rad, 
Spermatozoa and eggs were collected and washed as described previously (Garbers \& Hardman, 1976). Egg factors were obtained by allowing eggs (10-20 mg wet wt/ml) to set in seawater for 1-2 $\mathrm{h}$ and collecting the supernatant fluid above the eggs. This supernatant fluid is often termed 'egg water', and is known to elevate sperm cyclic AMP levels (Garbers \& Hardman, 1975, 1976), to stimulate respiration and motility, and to induce the acrosome reaction (Rothschild, 1956; Hathaway, 1963).

Spermatozoa (in $0.2 \mathrm{ml}$ seawater) were incubated immediately after being washed and were resuspended in a final reaction mixture of $0.65 \mathrm{ml}$ as described in the Tables. The incubations were initiated by the addition of spermatozoa to the assay tubes and were stopped by the addition of $1 \mathrm{ml}$ $0.5 \mathrm{~N}$-perchloric acid, containing tracer amounts of cyclic- $\left[{ }^{3} \mathrm{H}\right] \mathrm{AMP}$ or cyclic- $\left[{ }^{3} \mathrm{H}\right] \mathrm{GMP}$ for estimation of sperm cyclic nucleotide recoveries. The acidified cell suspensions were then frozen and thawed five times before purification of the cyclic nucleotides on Dowex-50 columns $(0.7 \mathrm{~cm} \times 25.0 \mathrm{~cm})$ as described by Schultz, Böhme \& Hardman (1974). The column fractions containing cyclic AMP or cyclic GMP were freeze dried and then resuspended in 0.5-1.0 ml distilled water. Cyclic AMP was assayed by the method of Gilman (1970), as modified by Brostrom \& Kon (1974). Cyclic GMP was determined by the radioimmunoassay of Steiner, Kipnis, Utiger \& Parker (1969), as modified by Harper \& Brooker (1975).

Various tissue extracts were also prepared for incubation with the spermatozoa. Hamster serum was collected and heated at $56^{\circ} \mathrm{C}$ for $35 \mathrm{~min}$ to inactivate the toxic serum component described by Yanagimachi (1970). Hamster uteri were removed and flushed with $0.9 \%(\mathrm{w} / \mathrm{v}) \mathrm{NaCl}$ solution. The flushings were centrifuged at $26000 \mathrm{~g}$ for $20 \mathrm{~min}$ and the resulting supernatant fluid was used in subsequent experiments. Hamster adrenal glands were removed, trimmed of excess tissue, and homogenized $(5-10 \mathrm{~g} / 100 \mathrm{ml})$ in $0.9 \%(\mathrm{w} / \mathrm{v}) \mathrm{NaCl}$ solution. The homogenate was centrifuged at $26000 \mathrm{~g}$ for $20 \mathrm{~min}$ and the supernatant fluid was removed and heated at $56^{\circ} \mathrm{C}$ for $30 \mathrm{~min}$. Hamster ovaries and rat lungs were removed, weighed and homogenized $(5-10 \mathrm{~g} / 100 \mathrm{ml})$ in $0.9 \%(\mathrm{w} / \mathrm{v}) \mathrm{NaCl}$ solution. The homogenate was then centrifuged at $26000 \mathrm{~g}$ for $20 \mathrm{~min}$ and the supernatant saved for incubation with the spermatozoa.

\section{Results}

The positive results are shown in detail in the Tables, but much of the negative data is not given.

\section{Effects of various agents in the presence or absence of theophylline}

As reported previously (Garbers \& Hardman, 1975, 1976) there was a marked synergistic effect between theophylline and FRE to elevate sperm cyclic AMP levels (Table 1). However, agents known to elevate cyclic nucleotide levels in other tissues (Robison, Butcher \& Sutherland, 1971; Kimura, Mittal \& Murad, 1975a, b), and other compounds failed to elevate sperm cyclic AMP or cyclic GMP levels.

Some of the incubations with these agents were extended for more than $1 \mathrm{~min}$. A23187, a divalent cation ionophore, was tested at 15 and $30 \mu \mathrm{g} / \mathrm{ml}$ in normal seawater and did not affect cyclic AMP or cyclic GMP levels after 1, 2, 5 or 10 min of incubation. However, in $\mathrm{Mg}^{2+}$-free seawater, the ionophore caused small but reproducible increases in sperm cyclic AMP concentrations in the presence of theophylline (Table 2). Thus, $\mathrm{Ca}^{2+}$ transport into the sperm cell may result in an elevation of cyclic AMP. A23187 significantly reduced the FRE-induced elevation of sperm cyclic AMP in the presence and absence of theophylline. Cyclic GMP concentrations were either decreased or not altered by the ionophore (Table 2).

Sodium azide, which possesses nucleophilic properties, has been reported to elevate cyclic GMP levels in various tissues (Kimura et al., 1975b) and to stimulate guanylate cyclase activity in broken cell preparations (Kimura et al., 1975a). This compound failed to elevate cyclic GMP levels at any concentration tested but depressed cyclic GMP levels at concentrations greater than $150 \mu \mathrm{M}$ : at $1 \cdot 5$ mM-azide, cyclic GMP concentrations were depressed by $78 \%$. Cyclic AMP levels were not affected by sodium azide at any concentration tested. Sodium nitroprusside $(0.15$ and $1.5 \mathrm{~mm})$ did not elevate either cyclic nucleotide. 
Table 1. The effect of various agents in the presence or absence of theophylline on sea urchin sperm cyclic AMP and cyclic GMP levels ( $\mathrm{nmol} / \mathrm{g}$ wet weight of spermatozoa)

\begin{tabular}{|c|c|c|c|c|}
\hline Addition & Concentration & $\begin{array}{c}\text { Theophylline } \\
(1.5 \mathrm{~mm})\end{array}$ & Cyclic AMP & Cyclic GMP \\
\hline \multirow[t]{2}{*}{ None } & - & - & $2.4 \pm 0.4$ & $0.78 \pm 0.06$ \\
\hline & & + & $4.6 \pm 0.4$ & $1.23 \pm 0.04$ \\
\hline \multirow[t]{2}{*}{ FRE } & - & - & $34 \cdot 1 \pm 2 \cdot 4$ & $0.49 \pm 0.03$ \\
\hline & & + & $117.0 \pm 2.4$ & $1 \cdot 19 \pm 0.05$ \\
\hline \multirow[t]{2}{*}{ Triiodothyronine } & $15 \mu \mathrm{g} / \mathrm{ml}$ & - & $3 \cdot 2 \pm 0.5$ & $0.85 \pm 0.04$ \\
\hline & & + & $4 \cdot 7 \pm 0.3$ & $1 \cdot 51 \pm 0 \cdot 16$ \\
\hline \multirow[t]{2}{*}{$\mathrm{X} 537 \mathrm{~A}$} & $15 \mu \mathrm{g} / \mathrm{ml}$ & - & $2.5 \pm 0.5$ & $0.89 \pm 0.06$ \\
\hline & & + & $4 \cdot 2 \pm 0.2$ & $1 \cdot 25 \pm 0 \cdot 16$ \\
\hline \multirow[t]{2}{*}{ A23187 } & $15 \mu \mathrm{g} / \mathrm{ml}$ & - & $2 \cdot 9 \pm 0.2$ & $0.75 \pm 0.05$ \\
\hline & & + & $5 \cdot 1 \pm 0.2$ & $1.59 \pm 0.11$ \\
\hline \multirow[t]{2}{*}{ Adenosine } & $77 \mu \mathrm{M}$ & 一 & $2.4 \pm 0.2$ & $0.75 \pm 0.05$ \\
\hline & & + & $5 \cdot 0 \pm 0 \cdot 2$ & $1.22 \pm 0.11$ \\
\hline \multirow[t]{2}{*}{ Guanosine } & $77 \mu \mathrm{M}$ & - & $2.9 \pm 0.3$ & $0.96 \pm 0.14$ \\
\hline & & + & $5.7 \pm 0.2$ & $1.25 \pm 0.17$ \\
\hline \multirow[t]{2}{*}{ Norepinephrine } & $77 \mu \mathrm{M}$ & - & $2 \cdot 9 \pm 0.3$ & $0.80 \pm 0.04$ \\
\hline & & + & $5.0 \pm 0.2$ & $1.21 \pm 0.06$ \\
\hline \multirow[t]{2}{*}{ Histamine } & $77 \mu \mathrm{M}$ & - & $2.2 \pm 0.2$ & $0.87 \pm 0.05$ \\
\hline & & + & $3.7 \pm 0.1$ & $0.95 \pm 0.13$ \\
\hline \multirow[t]{2}{*}{ Acetylcholine } & $77 \mu \mathrm{M}$ & - & $2 \cdot 1 \pm 0 \cdot 3$ & $0.80 \pm 0.05$ \\
\hline & & + & $4 \cdot 1 \pm 0.2$ & $1.48 \pm 0.10$ \\
\hline \multirow[t]{2}{*}{ Phenylephrine } & $77 \mu \mathrm{M}$ & - & $1.9 \pm 0.3$ & $0.99 \pm 0.04$ \\
\hline & & + & $4.0 \pm 0.3$ & $1.19 \pm 0.12$ \\
\hline \multirow[t]{2}{*}{ Procaine } & $77 \mu \mathrm{M}$ & - & $1.8 \pm 0.2$ & $0.98 \pm 0.05$ \\
\hline & & + & $3.6 \pm 0.2$ & $1.40 \pm 0.09$ \\
\hline \multirow[t]{2}{*}{ Propranolol } & $77 \mu \mathrm{M}$ & - & $2.2 \pm 0.4$ & $0.84 \pm 0.06$ \\
\hline & & + & $4.8 \pm 0.3$ & $1.23 \pm 0.11$ \\
\hline \multirow[t]{2}{*}{$\mathrm{MnCl}_{2}$} & $770 \mu \mathrm{M}$ & - & $3.0 \pm 0.4$ & $0.86 \pm 0.04$ \\
\hline & & + & $4 \cdot 3 \pm 0.3$ & $1.21 \pm 0.11$ \\
\hline \multirow[t]{2}{*}{ Azide } & $77 \mu \mathrm{M}$ & - & $2.3 \pm 0.4$ & $0.72 \pm 0.05$ \\
\hline & & + & $3.9 \pm 0.6$ & $1.09 \pm 0.12$ \\
\hline \multirow[t]{2}{*}{ Dinitrophenol } & $77 \mu \mathrm{M}$ & - & $2 \cdot 1 \pm 0.4$ & $0.92 \pm 0.04$ \\
\hline & & + & $4.7 \pm 1.0$ & $1.21 \pm 0.10$ \\
\hline
\end{tabular}

All values represent the mean \pm s.e.m. of 4 observations. All incubations were for 1 min at $15-17^{\circ} \mathrm{C}$, and each contained 20-25 mg (wet weight) spermatozoa.

Concentrations of acetylcholine $(77 \mu \mathrm{M})$ and physostigmine $(7 \cdot 7 \mu \mathrm{M})$ which are known to stimulate sperm motility (Nelson, 1972; McGrady \& Nelson, 1976) were tested in the presence and absence of $4 \%$ dimethylsulphoxide but there was no alteration of the cyclic nucleotide levels in sea urchin spermatozoa at 1, 3 or 6 min of incubation under these conditions.

Various fatty acids $(7 \cdot 7 \mu \mathrm{M})$ were also tested for effects on sperm cyclic nucleotide levels after incubation for $1 \mathrm{~min}$, but of those studied (arachidonic, myristic, oleic and palmitic) none affected sperm cyclic AMP or cyclic GMP levels.

\section{Effects of various agents on the FRE cyclic AMP-elevating activity}

FRE elevated sperm cyclic AMP levels approximately 10-fold (Table 3), but only the putative phosphodiesterase inhibitors, theophylline and 1-methyl-3-isobutylxanthine, acted in a synergistic manner with FRE to elevate sperm cyclic AMP levels. However, sodium azide and dinitrophenol appreciably inhibited the cyclic AMP elevation caused by FRE. FRE slightly depressed sperm cyclic GMP levels, and this decrease was not alleviated by a number of agents tested except for theophylline and 1-methyl-3-isobutylxanthine (Table 3). In $\mathrm{Mg}^{2+}$-free seawater, A23187 caused a significant decrease in the FRE-induced elevation of cyclic AMP (Table 2). 
Table 2. The effect of A23187 on cyclic nucleotide levels (nmol/g wet weight of spermatozoa) of sea urchin spermatozoa in $\mathrm{Mg}^{2+}$-free seawater

\begin{tabular}{lccc}
\hline Addition & $\begin{array}{c}\text { Theophylline } \\
(1.5 \mathrm{mM})\end{array}$ & Cyclic AMP & Cyclic GMP \\
\hline None & - & $2.7 \pm 0.3$ & $0.54 \pm 0.07$ \\
& + & $3.2 \pm 0.2$ & $0.89 \pm 0.14$ \\
A23187 & - & $2.3 \pm 0.1$ & $0.30 \pm 0.01^{*}$ \\
$(15.4 \mu \mathrm{g} / \mathrm{ml})$ & + & $3.4 \pm 0.2$ & $0.45 \pm 0.02$ \\
A23187 & - & $3.9 \pm 0.6$ & $0.31 \pm 0.03$ \\
$(31 \mu \mathrm{g} / \mathrm{ml})$ & - & $6.2 \pm 1.1^{*}$ & $0.55 \pm 0.04$ \\
FRE & + & $59.2 \pm 2.9$ & $0.45 \pm 0.09$ \\
& - & $176 \pm 10.1$ & $0.83 \pm 0.11$ \\
FRE $+\mathrm{A} 23187$ & + & $10.6 \pm 3.5^{*}$ & $0.17 \pm 0.03$ \\
$(31 \mu \mathrm{g} / \mathrm{ml})$ & $45.9 \pm 4.8^{*}$ & $0.44 \pm 0.03$ \\
\hline
\end{tabular}

All incubations were for $1 \mathrm{~min}$ at $15-17^{\circ} \mathrm{C}$. A23187 was added in a solution containing dimethylformamide; equal concentrations of this solvent were added to the incubation mixtures from which A23187 was excluded.

* Values (mean \pm s.e.m. of 4 observations) significantly different from those of respective control without A23187 $(P<0.05)$.

Table 3. The effect of various agents, in the presence or absence of factors released from sea urchin eggs (FRE), on cyclic nucleotide levels ( $\mathrm{nmol} / \mathrm{g}$ wet weight of spermatozoa) in sea urchin spermatozoa

\begin{tabular}{|c|c|c|c|c|}
\hline Addition & $\begin{array}{c}\text { Concentration } \\
(\mu \mathrm{M})\end{array}$ & FRE & Cyclic AMP & Cyclic GMP \\
\hline None & 一 & $\bar{t}$ & $\begin{array}{r}2.3 \pm 0.2 \\
23.9 \pm 0.9\end{array}$ & $\begin{array}{l}0.45 \pm 0.03 \\
0.30 \pm 0.02\end{array}$ \\
\hline $\mathbf{T}_{\mathbf{3}}$ & 77 & $\bar{t}$ & $\begin{aligned} 2.2 & \pm 0.05 \\
21.3 & \pm 4.2\end{aligned}$ & $\begin{array}{l}0.56 \pm 0.03 \\
0.42 \pm 0.02\end{array}$ \\
\hline A23187 & $15(\mu \mathrm{g} / \mathrm{ml})$ & $\bar{t}$ & $\begin{array}{r}2.4 \pm 0.2 \\
20.6 \pm 1.0\end{array}$ & $\begin{array}{l}0.58 \pm 0.04 \\
0.36 \pm 0.02\end{array}$ \\
\hline Adenosine & 77 & $\bar{t}$ & $\begin{array}{r}2.3 \pm 0.2 \\
16.0 \pm 0.6\end{array}$ & $\begin{array}{l}0.47 \pm 0.02 \\
0.36 \pm 0.01\end{array}$ \\
\hline Guanosine & 77 & $\bar{t}$ & $\begin{array}{r}2.0 \pm 0.1 \\
16.4 \pm 0.7\end{array}$ & $\begin{array}{l}0.51 \pm 0.03 \\
0.36 \pm 0.02\end{array}$ \\
\hline Phenylephrine & 77 & $\overline{+}$ & $\begin{array}{r}2.0 \pm 0.2 \\
16.5 \pm 1.5\end{array}$ & $\begin{array}{l}0.46 \pm 0.02 \\
0.36 \pm 0.03\end{array}$ \\
\hline Acetylcholine & 77 & $\overline{+}$ & $\begin{array}{r}2.1 \pm 0.1 \\
17.2 \pm 0.8\end{array}$ & $\begin{array}{l}0.49 \pm 0.03 \\
0.33 \pm 0.02\end{array}$ \\
\hline Azide & 385 & $\overline{+}$ & $\begin{array}{r}2.2 \pm 0.1 \\
10.3 \pm 0.6\end{array}$ & $\begin{array}{l}0.34 \pm 0.02 \\
0.33 \pm 0.04\end{array}$ \\
\hline Dinitrophenol & 77 & $\overline{+}$ & $\begin{array}{r}2.2 \pm 0.1 \\
11.3 \pm 0.4\end{array}$ & $\begin{array}{l}0.52 \pm 0.02 \\
0.36 \pm 0.02\end{array}$ \\
\hline Theophylline & 1500 & $\overline{+}$ & $\begin{array}{c}4 \cdot 1 \pm 0.3 \\
79 \cdot 0 \pm 12 \cdot 0\end{array}$ & $\begin{array}{l}0.68 \pm 0.04 \\
0.74 \pm 0.08\end{array}$ \\
\hline 1-Methyl-3-isobutylxanthine & 150 & $\overline{+}$ & $\begin{array}{r}4.5 \pm 0.2 \\
82.0 \pm 6.0\end{array}$ & $\begin{array}{l}0.75 \pm 0.04 \\
0.82 \pm 0.04\end{array}$ \\
\hline
\end{tabular}

All values represent the mean \pm s.e.m. of 4 observations. Incubations, each containing 20-30 mg spermatozoa, were for $1 \mathrm{~min}$ at $15-17^{\circ} \mathrm{C}$.

\section{Effects of tissue extracts on sperm cyclic nucleotide levels}

Hamster serum and adrenal extracts have been reported to contain a substance of low molecular weight which stimulates hamster sperm motility (Bavister, Yanagimachi \& Teichman, 1976). In the present study only sea urchin FRE caused an elevation in sperm cyclic AMP levels (Table 4). Likewise, sperm cyclic GMP levels were not affected by any of the added tissue extracts (Table 4). 
Table 4. The effect of various tissue fluids on the cyclic nucleotide levels ( $\mathrm{nmol} / \mathrm{g}$ wet weight spermatozoa) in sea urchin spermatozoa

\begin{tabular}{|c|c|c|c|c|}
\hline Species & Tissue & $\begin{array}{c}\text { Theophylline } \\
\text { (1.5 mM) }\end{array}$ & Cyclic AMP & Cyclic GMP \\
\hline None & - & $\overline{+}$ & $\begin{array}{l}3.1 \pm 0.4 \\
4.9 \pm 0.5\end{array}$ & $\begin{array}{l}0.37 \pm 0.05 \\
0.52 \pm 0.03\end{array}$ \\
\hline Sea urchin & FRE & $\overline{+}$ & $\begin{array}{r}44 \cdot 1 \pm 2 \cdot 4 \\
127 \pm 6 \cdot 7\end{array}$ & $\begin{array}{l}0.33 \pm 0.03 \\
0.78 \pm 0.05\end{array}$ \\
\hline Ox & Serum albumin & $\overline{+}$ & $\begin{array}{l}3.0 \pm 0.4 \\
4.6 \pm 0.9\end{array}$ & $\begin{array}{l}0.31 \pm 0.02 \\
0.48 \pm 0.04\end{array}$ \\
\hline Hamster & $\begin{array}{l}\text { Serum } \\
\text { Uterine fluid } \\
\text { Adrenal } \\
\text { Ovary }\end{array}$ & $\begin{array}{l}\overline{+} \\
\frac{+}{+} \\
\frac{+}{+}\end{array}$ & $\begin{array}{l}2.4 \pm 0.4 \\
3.3 \pm 0.4 \\
2.7 \pm 0.3 \\
3.8 \pm 0.7 \\
3.8 \pm 1.0 \\
3.9 \pm 0.6 \\
2.5 \pm 0.2 \\
3.3 \pm 0.2\end{array}$ & $\begin{array}{l}0.38 \pm 0.03 \\
0.94 \pm 0.27 \\
0.31 \pm 0.02 \\
0.61 \pm 0.28 \\
0.36 \pm 0.02 \\
0.52 \pm 0.04 \\
0.43 \pm 0.07 \\
0.62 \pm 0.06\end{array}$ \\
\hline Rat & Lung & $\overline{+}$ & $\begin{array}{l}2.9 \pm 0.4 \\
2.8 \pm 0.4\end{array}$ & $\begin{array}{l}0.41 \pm 0.04 \\
0.66 \pm 0.06\end{array}$ \\
\hline
\end{tabular}

All values represent the mean \pm s.e.m. of 4 observations. All incubations $(0.65 \mathrm{ml})$ were for $1 \mathrm{~min}$ at $15-17^{\circ} \mathrm{C}$ and each contained $15-25 \mathrm{mg}$ (wet weight) of spermatozoa and $50 \mu \mathrm{l}$ of each tissue fluid or extract.

\section{Discussion}

The chemical nature of the substance(s) released by sea urchin eggs remains to be determined, but they apparently do not resemble a number of agents (e.g. triiodothyronine, adenosine, norepinephrine, histamine, acetylcholine and phenylephrine) that are known to alter cyclic AMP levels in other tissues. The divalent cation ionophores (X537A and A23187) also failed to alter cyclic nucleotide levels in normal seawater, but A23187 caused elevations in sperm cyclic AMP levels in $\mathbf{M g}^{2+}$-free seawater, suggesting that $\mathrm{A} 23187-$ mediated $\mathrm{Ca}^{2+}$ transport might be responsible for the elevation of cyclic AMP. The cyclic AMP elevations are slight, however, and A23187 actually inhibits the FREinduced elevation of sperm cyclic AMP. Therefore, FRE probably do not elevate sperm cyclic AMP by a similar mediation of $\mathrm{Ca}^{2+}$-transport.

The experiments with mammalian tissues demonstrate that cyclic AMP levels of sea urchin spermatozoa are elevated specifically by factor(s) associated with the sea urchin egg. The origin of the FRE remains to be clarified. Sea urchin eggs are surrounded by a jelly coat but it is not yet known whether the cyclic AMP-elevating activity is associated with the jelly coat or diffuses from the egg itself.

We thank Ms D. Janette Tubb, Ms Helen Davis Watkins and Ms Marvist A. Parks for their excellent technical assistance. The work was supported by NIH grants HD 05797, HD 10254, GM 16811 and AM 07462. D.L.G. is an Investigator for the Howard Hughes Medical Institute.

\section{References}

Bavister, B.D., Yanagimachi, R. \& Teichman, R.J. (1976) Capacitation of hamster spermatozoa with adrenal gland extracts. Biol. Reprod. 14, 219-221.

Braun, T. \& Dods, R.F. (1975) Development of a $\mathrm{Mn}^{2+}$-sensitive "soluble" adenylate cyclase in rat testis. Proc. natn. Acad. Sci. U.S.A. 72, 1097-1101.

Brostrom, C.O. \& Kon, C. (1974) An improved protein binding assay for cyclic AMP. Analyt. Biochem. 58, 459-468.

Casillas, E.R. \& Hoskins, D.D. (1971) Adenyl cyclase activity and cyclic $3^{\prime}, 5^{\prime}$-AMP content of ejaculated monkey spermatozoa. Archs Biochem. Biophys. 147, 148-155.

Frenkel, G., Peterson, R.N. \& Freund, M. (1973) The role of adenine nucleotides and the effect of caffeine and dibutyryl cyclic AMP on the metabolism of guinea pig epididymal spermatozoa. Proc. Soc. exp. Biol. Med. 144, 420-425.

Garbers, D.L. (1977) Characterization of sea urchin sperm adenylate cyclase. Biol. Reprod. 16, 377-384.

Garbers, D.L. \& Hardman; J.G. (1975) Factors released from sea urchin eggs affect cyclic nycleotide 
metabolism in sperm. Nature, Lond. 257, 677-678.

Garbers, D.L. \& Hardman, J.G. (1976) Effects of egg factors on cyclic nucleotide metabolism in sea urchin sperm. J. cyclic Nucleotide Res. 2, 59-70.

GARbERs, D.L., Lusr, W.D., FirST, N.L. \& LARDY, H.A. (1971 a) Effects of phosphodiesterase inhibitors and cyclic nucleotides on sperm respiration and motility. Biochemistry, N. Y. 10, 1825-1831.

Garbers, D.L., First, N.L., Sullivan, J.J. \& Lardy, H.A. (1971b) Stimulation and maintenance of ejaculated bovine spermatozoan respiration and motility by caffeine. Biol. Reprod. 5, 336-339.

Garbers, D.L., First, N.L. \& Lardy, H.A. (1973a) The stimulation of bovine epididymal sperm metabolism by cyclic nucleotide phosphodiesterase inhibitors. Biol. Reprod. 8, 589-598.

Garbers, D.L., First, N.L., Gorman, S.K. \& Lardy, H.A. (1973b) The effects of cyclic nucleotide phosphodiesterase inhibitors on ejaculated porcine spermatozoan metabolism. Biol. Reprod. 8, 599-606.

Garbers, D.L., First, N.L. \& LARDY, H.A. (1973c) Properties of adenosine 3'-5'-monophosphate-dependent protein kinases isolated from bovine epididymal spermatozoa. J. biol. Chem. 248, 875-879.

Garbers, D.L., HaRdMan, J.G. \& RUdOlPh, F.B. (1974) Kinetic analysis of sea urchin sperm guanylate cyclase. Biochemistry, N.Y. 13, 4166-4171.

GilmaN, A.G. (1970) A protein binding assay for adenosine 3',5'-cyclic monophosphate. Proc. natn. Acad. Sci. U.S.A. 67, 305-312.

GRAY, J.P., DRUMMOND, G.I., LUK, D.W.T., HARdMAN, J.G. \& Sutherland, E.W. (1976) Enzymes of cyclic nucleotide metabolism in invertebrate and vertebrate sperm. Archs Biochem. Biophys. 172, 20-30.

HARPer, J.F. \& Brooker, G. (1975) Femtomole sensitive radioimmunoassay for cyclic AMP and cyclic GMP after $2 \%$ acetylation by acetic anhydride in aqueous solution. $J$. cyclic Nucleotide Res. 1, 207218.

Hathaway, R.R. (1963) Activation of respiration in sea urchin spermatozoa by egg water. Biol. Bull. mar. Biol. Lab. Woods Hole 125, 486-498.

Herman, C.A., Zahler, W.L., Doak, G.A. \& Campbell, B.J. (1976) Bull sperm adenylate cyclase : localization and partial characterization. Archs Biochem. Biophys. 117, 622-629.

Hoskins, D.D. (1973) Adenine nucleotide mediation of fructolysis and motility in bovine epididymal spermatozoa. J. biol. Chem. 248, 1135-1140.

Hoskins, D.D. \& Casillas, E.R. (1974) Hormones, second messengers, and the mammalian spermatozoa. In Advances in Sex Hormone Research, Vol. 1, pp. 283-324. Eds R. L. Singhal \& J. A. Thomas. University Park Press, Baltimore.

Hoskins, D.D., Casillas, E.R. \& Stephens, D.T. (1972) Cyclic AMP-dependent protein kinases of bovine epididymal spermatozoa. Biochem. Biophys. Res. Commun. 48, 1331-1338.

Kimura, H., Mittal, C.K. \& Murad, F. (1975a) Activation of guanylate cyclase from rat liver and other tissues by sodium azide. J. biol. Chem. 250, 8016-8022.
Kimura, H., Mittal, C.K., \& Murad, F. (1975b) Increase in cyclic GMP levels in brain and liver with sodium azide an activator of guanylate cyclase. Nature, Lond. 257, 700-702.

Kopf, G.S. \& Garbers, D.L. (1977) Elevation of sea urchin sperm cAMP levels and respiratory rates by factor(s) released from eggs. Fedn Proc. Fedn Am. Socs exp. Biol. 36, 347, Abstr.

LeE, M.Y.W. \& IVERson, R.M. (1976) An adenosine 3':5'-monophosphate dependent protein kinase from sea urchin spermatozoa. Biochim. biophys. Acta 429, 123-136.

McGrady, A.V. \& Nelson, L. (1976) Cholinergic effects on bull and chimpanzee sperm motility. Biol. Reprod. 15, 248-253.

MORTON, B. \& ALBAGLl, L. (1973) Modification of hamster sperm adenyl cyclase by capacitation in vitro. Biochem. Biophys. Res. Commun. 50, 697-703.

Morton, B., Harrigan-Lum, J., Albagli, L. \& Jooss, T. (1974) The activation of motility in quiescent hamster sperm from the epididymis by calcium and cyclic nucleotides. Biochem. Biophys. Res. Commun. 56, 372-379.

Nelson, L. (1972) Neurochemical control of Arbacia sperm motility. Expl Cell Res. 74, 269-274.

Robison, G.A., Butcher, R.W. \& Sutherland, E.W. (1971) Cyclic AMP. Academic Press, New York.

ROGERS, B.J. \& MORTON, B. (1973) ATP levels in hamster spermatozoa during capacitation in vitro. Biol. Reprod. 9, 36I-369.

Rosado, H., Hicks, J.J., Reyes, A. \& Blanco, I. (1974) Capacitation in vitro of rabbit spermatozoa with cyclic adenosine monophosphate and human follicular fluid. Fert. Steril. 25, 821-824.

RothsCHILd, LoRd (1956) Fertilization. John Wiley and Sons, Inc., New York.

Schoenfeld, C., Amelar, R.D. \& Dubin, L. (1975) Stimulation of ejaculated human spermatozoa by caffeine. Fert. Steril. 26, 158-161.

Schultz, G., Böhme, E. \& Hardman, J.G. (1974) Separation and purification of cyclic nucleotides by ion-exchange resin column chromatography. Methods Enzym. 38, 9-20.

Steiner, A.L., Kipnis, D.M., Utiger, R. \& Parker, C. (1969) Radioimmunoassay for the measurement of adenosine 3',5'-cyclic phosphate. Proc. natn. Acad. Sci. U.S.A. 64, 367-373.

TANG, F.Y. \& Hoskins, D.D. (1975) Phosphoprotein phosphatase of bovine epididymal spermatozoa. Biochem. Biophys. Res. Commun. 62, 328-335.

TAsH, J.G. (1976) Investigations on adenosine $3^{\prime}, 5^{\prime}-$ monophosphate phosphodiesterase in ram semen and initial characterization of a sperm-specific isoenzyme. J. Reprod. Fert. 47, 63-72.

Toyoda, T. \& Chang, M.C. (1974) Capacitation of epididymal spermatozoa in a medium with high $\mathrm{K} / \mathrm{Na}$ ratio and cyclic AMP for the fertilization of rat eggs in vitro. J. Reprod. Fert. 36, 125-134.

Wells, J.N. \& Garbers, D.L. (1976) Nucleoside 3',5'monophosphate phosphodiesterases in sea urchin sperm. Biol. Reprod. 15, 46-53.

YANAGIMACHI, R. (1970) In vitro capacitation of golden hamster spermatozoa by homologous and heteroloDown lo gous blood sera. Biol. Reprod. 3, 147 $\angle$-153.023 01 : 11: $27 \mathrm{PM}$ 